\title{
"The impact of ethical leadership on employee engagement within a South African public higher education institution"
}

\begin{tabular}{|c|c|}
\hline \multirow{3}{*}{ AUTHORS } & Anrusha Bhana id https://orcid.org/0000-0001-5577-6728 \\
\hline & \multirow{2}{*}{$\begin{array}{l}\text { R https://publons.com/researcher/ABE-6081-2021/ } \\
\text { Sachin Suknunan D https://orcid.org/0000-0002-7296-8059 }\end{array}$} \\
\hline & \\
\hline ARTICLE INFO & $\begin{array}{l}\text { Anrusha Bhana and Sachin Suknunan (2019). The impact of ethical leadership } \\
\text { on employee engagement within a South African public higher education } \\
\text { institution. Problems and Perspectives in Management, 17(4), 314-324. } \\
\text { doi:10.21511/ppm.17(4).2019.26 }\end{array}$ \\
\hline DOI & http://dx.doi.org/10.21511/ppm.17(4).2019.26 \\
\hline RELEASED ON & Wednesday, 25 December 2019 \\
\hline RECEIVED ON & Wednesday, 04 September 2019 \\
\hline ACCEPTED ON & Friday, 29 November 2019 \\
\hline & $((c)) \overline{E Y}$ \\
\hline LICENSE & $\begin{array}{l}\text { This work is licensed under a Creative Commons Attribution } 4.0 \text { International } \\
\text { License }\end{array}$ \\
\hline JOURNAL & "Problems and Perspectives in Management" \\
\hline ISSN PRINT & $1727-7051$ \\
\hline ISSN ONLINE & $1810-5467$ \\
\hline PUBLISHER & LLC “Consulting Publishing Company "Business Perspectives" \\
\hline FOUNDER & LLC "Consulting Publishing Company "Business Perspectives" \\
\hline & 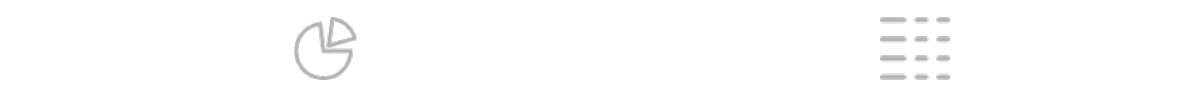 \\
\hline NUMBER OF REFERENCES & NUMBER OF FIGURES \\
\hline 62 & 0 \\
\hline
\end{tabular}

(C) The author(s) 2022. This publication is an open access article. 


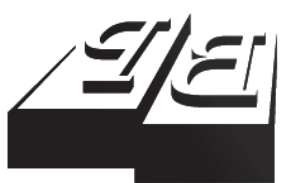

BUSINESS PERSPECTIVES

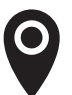

LLC "CPC "Business Perspectives" Hryhorii Skovoroda lane, 10, Sumy, 40022, Ukraine

www.businessperspectives.org

Received on: $4^{\text {th }}$ of September, 2019 Accepted on: 29 th of November, 2019

(C) Anrusha Bhana,

Sachin Suknunan, 2019

Anrusha Bhana, Ph.D., Department of Financial Accounting, Durban University of Technology, South Africa.

Sachin Suknunan, Doctor of Business Administration, Student Services Division, University of KwaZuluNatal, South Africa.

\section{THE IMPACT OF ETHICAL LEADERSHIP ON EMPLOYEE ENGAGEMENT WITHIN A SOUTH AFRICAN PUBLIC HIGHER EDUCATION INSTITUTION}

\begin{abstract}
Ethical leadership has become a fundamental building block amongst the corporate organizations globally. However, minimal research evidence was found from a higher education institution (HEI) perspective, including the evidence from a South African higher education setting. Due to the lack of research linking the ethical leadership's style and employee's engagement (EE) at higher education institutions, it becomes important to find out if ethical leadership can positively promote the EE, which, in turn, can promote various other benefits at the institutions. Therefore, this study aims to examine this from the perspective of ethical leadership style and its impact on the EE. This study focused on a large HEI (Higher Education institution) based in KwaZuluNatal (South Africa). Quantitative data collection employed the probability sampling targeting 420 employees. Questionnaires were used as data collection tools and obtained a response rate of $312(74 \%)$. The results show that the average mean value for $\mathrm{EE}(\mathrm{M}=2.87)$ was weak in comparison to the measurement standard of 3.00 , which implied a lack of EE between leadership and employees. In addition, the results indicate that ethical leadership can positively influence the EE $(M=4.27)$, thus, indicating the need for more ethical leadership at this institution. Furthermore, the current lack of employee's engagement by leaders that do not exhibit the ethical leadership style can result in employees' disengagement at the institution.
\end{abstract}

\section{Keywords}

JEL Classification employees, engagement, higher education institution, ethical leadership

\section{INTRODUCTION}

Employee's engagement (EE) is often underestimated and under-represented when it comes to ethical leadership. The paper examines the ethical leadership style from the perspective of the EE. The African continent's development agenda should be to turn the leadership skills into strategic assets, and universities must be proactive in developing the institutional leadership (Hanson \& Léautier, 2011, p. 391). There is a need for higher education (HE) leaders to develop new skills and leadership practices to respond effectively to transformation challenges (Herbst \& Conradie, 2011, p. 12). Hence, South African HEIs need to ensure that leadership development is a priority at all levels. Over the years, line management leadership (hereafter referred to as LML) have led the departments akin to their predecessors, without any foresight on the impact that leadership has on the EE. Management styles influence both the output and the well-being of employees (Van Niekerk, De Klerk, \& Pires-Putter, 2017, p. 221, in Friedman, Tidd, Currall, \& Tsai, 2000; Wright, 2011). According to Detert, Treviño, and Sweitzer (2008, p. 386), some organization leaders may possibly influence the 
existing employees that are susceptible to moral disengagement. Notably, HE employees are regularly under stress from the internal environment (workloads, research outputs, student matters, administrative issues, etc.) and external environment (public funding, autonomy issues, and transformation). Conflict happens when staff is not able to work as a team to achieve the institutional goals and objectives. These disputes influence the HEIs culture and work environment (Du Toit, 2000) and affect the academics and support staff engaged in the academic process (Van Niekerk et al., 2017, p. 3). Inherently, the impact of ineffective leadership and employee's disengagement will not only affect the staff but will also have a ripple effect on the stakeholders. In light of this, the EE becomes a critical component and requires in-depth examination within the HE context.

\section{LITERATURE REVIEW}

\subsection{Employees and leadership behavior}

Research has revealed that the leaders' behaviors will affect an employee's level of engagement (Breevaart, Bakker, Hetland, Demerouti, Olsen, \& Espevik, 2014). An individual's behavioral style is learnt to a certain degree by observing the action of noteworthy person/s and emulating those behaviors if it shows desirable results (Heres \& Lasthuizen, 2013, p. 88, cited in Bandura, 1977, 1986). Moreover, if leaders behave correctly and fulfil the expected leadership roles, odds are that the followers will be more pleased with the leader and respond (Van Zyl, Dalgish, du Plessis, Lues, Pietersen, Ngunjiri, \& Kablan, 2016, p. 9, cited in Dalglish).Leaders with the passion, vision, and courage to mentor the teams should become the catalysts and build the environments that will inspire and release the vigor of employees (Denton \& Vloeberghs, 2003, p. 88). Furthermore, employees who are empowered respond faster to changes in the environment and stakeholder demands in comparison to disempowered employees (Carson \& King, 2005, pp. 1049-1053). Hence, employee empowerment practices demonstrate high levels of engagement (Greco, Laschinger, \& Wong, 2006, pp. 41-56).

\subsection{Ethical leadership definition and style}

Ethical leadership style can be defined exhibiting the appropriate conduct and showing the followers' proper behavior by way of suitable communication, support, and decision-making (Brown, Treviño, \& Harrison, 2005, p. 120). According to Eisenbeiss and Brodbeck (2014, p. 343), leader- ship ethics ought to be at the core of the corporate world. It is the connection between leaders and followers that places the ethics fundamental to leadership (Van Zyl et al., 2016, p. 172, cited in Pietersen, 2016).

Ethical leadership style postulates that there is a simple basic difference between right and wrong, and an ethical leader is the one who does what is correct (Oates, 2013, p. 38). According to Quintal (2012, p. 2, cited in Madonsela, 2012) ethical leadership is the epitome of the sustainable leadership in one's personal and professional life. Clearly, Brown (2007, p. 149) believes that over time, ethical leadership and effective leadership have been seen as compatible leadership styles that have gained momentum. Ethical leadership impacts the work relationships, as well as other organizational outcomes and expected to have a positive influence on work engagement (Engelbrecht, Heine, \& Mahembe, 2014, p. 2). Engelbrecht, Heine, and Mahembe $(2014$, p. 3) assert that ethical leadership style embraces diverse qualities that are evident in the trusting relationship between a leader and a follower.

Interestingly, Brown, Treviño, and Harrison (2005) claimed that ethical leadership is linked to better employee motivation and more positive work performance. Employees who are observing leaders will be influenced by the ethical behavior observed and the leader's skills, not a general view related to only human nature (Brown, Treviño, \& Harrison, 2005, p. 121). It is noteworthy that Kalshoven and Den Hartog (2009, p. 102) believe that ethical leadership style is supposed to improve the trust among employees, and these leaders would then be regarded as effective leaders. From a tangible perspective, ethical leadership can reduce the cases of exploitation, fraud, deceit, intimidation, or 
mismanagement of financial resources (Heres \& Lasthuizen, 2013, p. 94, cited in Khuntia \& Suar, 2004; Lasthuizen, 2008). Moreover, ethical leadership of King IV report is epitomized by honesty, competency, responsibility, accountability, impartiality, and transparency (KMPG, 2016).

\subsection{Engagement and employee's engagement}

Engagement is said to be a blend of attitude and behavior whereby the attitude is seen as dedication and behavior is going the extra mile (Dromey, 2014, p. 7, cited in Purcell, 2010, p. 3). Schaufeli, Salanova, Gonzalez-romá, and Bakker (2002, p. 74) defined the engagement as an affirmative, achieving, job-related mind-set, characterized by vigor, perseverance, and interest. Similarly, Schaufeli and Bakker (2001, pp. 229-253) define the engagement as an encouraging, satisfying, job-related outlook that is characterised by vigor (energy), perseverance (commitment), and absorption (engagement), which relates to Shaw and Bastock (2005) whereby the EE is defined as a translation of employees' capability into better employee performance and organizational success, thus, transforming the way employees work.

Employee engagement literature has acknowledged the managers as key engagement enablers (Lewis, Brychan, \& Owen, 2012, p. 46, cited in Rama Devi, MacLeod, \& Clarke, 2009; Luthan \& Peterson, 2002, Tomlinson, 2010). EE is about forming the right environment in which the employees have the ability and potential to give ones best every day (Hirtle, 2016). Swarnalatha and Prasanna (2013, p. 3875) maintain that employee participation, work participation, behavioral commitment, stakeholder engagement, and staff engagement are a few carefully related concepts.

Employee engagement concerns an individual and not multitudes of employees, as it is an individual decision that cannot be instructed or enforced (Shuck \& Wollard, 2010, p. 102). Most of the EE literature has often focused on the organizational level, however, the EE is an individual-level construct that needs to be better understood from the perspective of each person, unit, and team (Shuck \& Wollard, 2010, pp. 105-106). As stated by Takawira, Coetzee, and Schreuder (2014, pp. 3-4), engaged employees were positive towards their job, thus, leading to efficiency. Cropanzano and Wright (2001, pp. 182-199) claim that engaged employees were more open to work opportunities, more self-assured, and positive. Noticeably, as claimed by Halbesleben and Wheeler (2008, pp. 242-256), Mitchell, Holton, Lee, and Graske (2001, pp. 96-109), job embeddedness, and the EE constructs may have a significant impact on employees' turnover intention. According to Devi (2009, pp. 3-4), engaged employees are aware of the organizations' framework and work with others within that domain to improve the performance for the benefit of the organization.

\subsection{Employee's engagement for higher education institutions}

Gallup (2016, p. 2) asserted that universities are amongst the least engaged workplaces in the world, as universities are not capitalizing on the potential of the biggest asset - faculty and employees. Interestingly, leadership behavior is known to have a powerful impact on the EE, turnover, and organizational consequences (Chen \& Silverthorne, 2005, pp. 280-288). Rothmann and Jordaan (2006, pp. 87-96) claim that the existing research on the EE tends to concentrate on corporate organizations with less attention from researchers and practitioners on engagement in the HE settings. Notably, Barkhuizen and Rothmann (2008, p. 322) claim that HEIs need to manage and protect the employees from high levels of stress to preserve the staff well-being, organizational performance, and the intellectual well-being of a country. However, unawareness of EE is puzzling, given that HEIs are also facing the forces of globalization that is parallel to corporate organizations (Sullivan, Bartlett, \& Rana, 2015, p. 4).

Few studies at HEIs have been conducted on the EE (Field \& Buitendach, 2011, p. 5, cited in Coetzee \& Rothmann, 2005; Jackson, Rothmann, \& Van de Vijver, 2006; Rothmann \& Jordaan, 2005, pp. 263-274). Interestingly, institutional changes that are essential for transformation at HEIs also have a direct influence on the EE (Bezuidenhout \& Cilliers, 2010, p. 2). Vigor amongst SA academics is clearly connected to career development opportunities in and relatively associated with organizational collaboration (Rothmann \& Jordaan, 2006, pp. 87-96). 
Table 1 reflects the measured employee engagement study findings by Sullivan et al. (2015, p. 14).

Table 1. Constructs measured by the University employee engagement study

Source: Adapted from Sullivan et al. (2015, p. 14).

\begin{tabular}{|c|c|}
\hline $\begin{array}{l}\text { Construct } \\
\text { measured }\end{array}$ & Findings \\
\hline Engagement & $\begin{array}{l}\text { Commitment, drive, and care for the } \\
\text { work and the organization }\end{array}$ \\
\hline $\begin{array}{l}\text { Effectiveness of the } \\
\text { work environment }\end{array}$ & $\begin{array}{l}\text { Settings that allow for employees' } \\
\text { effectiveness and eliminate barriers to } \\
\text { output }\end{array}$ \\
\hline Engagement drivers & $\begin{array}{l}\text { - Link to department strategy and } \\
\text { - } \text { Soals } \\
\text { - education, research, and service } \\
\text { - Open communications and trust in } \\
\text { leaders } \\
\text { - Support for staff professional and } \\
\text { job growth } \\
\text { - Acknowledgement and respect for } \\
\text { staff and contributions } \\
\text { - Autonomy and inspiration for } \\
\text { innovation } \\
\text { - Clear performance potentials and } \\
\text { consistent feedback } \\
\text { - Collaboration and sharing of ideas } \\
\text { within and across departments } \\
\text { - Skills, information, and resources } \\
\text { required to do the job well } \\
\text { - Impartial workload and support for } \\
\text { improving job processes }\end{array}$ \\
\hline
\end{tabular}

South African academics are compelled to yield more research outputs, lecture larger classes and supervise more postgraduate students. Hence, the substantial workloads with inadequate support and fewer resources require more time and vigor (Bezuidenhout \& Cilliers, 2010, p. 1). Furthermore, human resources development in HEIs remains of the highest importance because of the need to sustain the qualified academic and administrative employees in order to offer the quality education (Deligero \& Laguador, 2014, pp. 909-917).

\subsection{Leadership and employee engagement relationship}

Robust manager-employee relationship is an essential constituent in the employee engagement and retention formula (Kompaso \& Sridevi, 2010, p. 91). According to Dromey (2014, cited in MacLeod \& Clarke, 2009, p. 31), the role of leadership in setting out the strategic narrative is to make sure that the employees understand it and see how employees influence it. Distinctly, a mor- al leader in the university does not treat the employees like petty criminals. When somebody does something erroneous, the leader should deal with it, but also respect the other person's views (Council of Higher Education, 2016, p. 4, cited in Saunders, 2016, p. 5).

Cawe (2006, p. 29, cited in Gallup institute, 2003), five essential skills of alignment, inclusion, mentoring, team development, and building of trust are what leaders need to have to succeed at improving the EE. Similarly, Masemola (2011, p. 32) maintains that management should develop the effective and efficient ways to understand what employees want or potential rewards and expand the employees' job satisfaction within an organization. In addition, the more transparent the managers are in terms of the organization's processes and procedures, the more engaged the employees will be (Konrad, 2006, pp. 1-6). Importantly, SAIPA (2017, p. 11) asserts that when a leader is ethical and has integrity, employees will tell the leader what he/she needs to hear, but does not want to hear. Job resources (such as organizational support and development opportunities) knowingly predicted the EE of academics in many South African HEIs (Rothmann \& Jordaan, 2006, p. 95). Hence, without university employees willing to go above and beyond, scholars are less likely to be engaged in education and be equipped for life (Gallup, 2016, p. 2).

\subsection{Ethical leadership style impact on employee engagement}

Ethical leadership is related to employees' inclination to inform the leaders of difficulties (Brown and Treviño, 2006, p. 123). Moreover, Butcher (1997, pp. 83-87) claims that to establish an ethical role model, leaders cannot ignore the responsibilities and duties for those that are being led. Ethical leaders are known to establish an atmosphere that positively influences the employee's goals and behavior (Mayer, Kuenzi, Greenbaum, Bardes, \& Salvador, 2009, pp. 1-13). Furthermore, ethical leadership ensures that the employees have a better work outlook and are more committed and immersed in the job (Brown et al., 2005). To ensure job satisfaction of employees' attention should be given to the leadership and management styles, individuals in management positions, namely exec- 
utive managers and departmental heads (Schulze, 2006, p. 322, cited in Venter, 1998).

According to Treviño, Brown, and Hartman (2000, pp. 128-142; 2003, pp.5-37), leaders become attractive and credible ethical role models when observed by the employees as both a moral being and a moral leader. Furthermore, Heres and Lasthuizen (2013, p. 96) maintain that ethical leadership also influences the employees' relationship with the leader, team, and general organization. Ethical leadership fosters the trust not only in the leader but also amongst the colleagues (De Hoogh \& Den Hartog, 2008). As asserted by Engelbrecht, Heine, and Mahembe $(2014$, p. 3, cited in Zhu, May, \& Avolio, 2004, pp. 16-26), ethical leadership includes the employees in the decision-making process, as well as enables the employee's well-being and development. According to Kalshoven and Boon (2012, p. 60), ethical leaders offer such job resources as role explanation or open support, therefore, ethical leadership communicates positively to employee well-being. Treviño, Hartman, and Brown (2000, pp. 5-37; 2003, pp. 128-142) claimed that showing the concern for individuals and unbiased treatment of employees contribute to ethical leadership behavior.

The diverse literature review serves as a framework for the importance of ethical leadership style relative to the EE within a South African HE context.

\section{AIMS}

The paper aims to explore the phenomena of ethical leadership and employee's engagement with the primary aim/hypothesis of establishing if ethical leadership style significantly influences the EE.

\section{RESEARCH METHODOLOGY}

The paper extracted the data from a quantitative approach, using the probability sampling technique. The quantitative approach involved the probability technique using the simple random sampling, as the technique provides a guarantee that chosen representatives (employees) were a sample of the larger study population. Hence, the quantitative sample constituted to a target of 420 staff members (out of a population of 1,874 ) at the institution. Survey questionnaires were used for the quantitative study as data collection tools. The questionnaires were distributed to the sample of 420 respondents and obtained a response rate of 312 (74\%).

\section{ANALYSIS OF DATA}

Quantitative analyses was performed on the data to promote strong validation of findings. This entailed both descriptive and inferential statistics.

\subsection{Descriptive statistics}

Frequency statistics were used to describe the disagreement or agreement levels of employees when it came to the EE. This is reflected in Table 2.

Table 2 demonstrated the frequency distribution using 15 Likert five-point scale statements (from strongly disagree to strongly agree), mean value scores and standard deviation ranging from the highest mean of $\mathrm{M}=3.86(\mathrm{SD}=1.038)$ to the lowest mean of $\mathrm{M}=2.33$ ( $\mathrm{SD}=1.136$ ) for the $\mathrm{EE}$ construct. The mean value scores and standard deviation for respondents have been reported in the descending order. Noticeably, the average mean value $(\mathrm{M}=2.87, \mathrm{SD}=0.115)$ for overall statements has shown a weak mean value score of less than 3.00 .

Thus, the results show that currently there is a lack of the EE between leadership and employees, and further indicated a weak relationship between leadership and employee engagement.

Leadership dimension concepts are shown in Table 2, which includes the ethical leadership impact on the employees.

Table 3 presented the leadership dimension concept that utilized 4 Likert five-point scale statements (from strongly disagree to strongly agree). The average mean value amounted to $M=4.27$, $\mathrm{SD}=0.093$, and this was much higher than the mean measurement value of 3.00. The results imply that the majority of respondents believed that ethical leadership style can have a positive impact on the employees. 
Table 2. Employee's engagement

\begin{tabular}{|c|c|c|c|c|c|c|c|c|}
\hline \multirow{2}{*}{\multicolumn{2}{|c|}{ Employee engagement }} & \multicolumn{5}{|c|}{ Likert scale } & \multirow{2}{*}{ Mean } & \multirow{2}{*}{ Std. dev. } \\
\hline & & \multirow{2}{*}{$\begin{array}{l}\text { SD } \\
12\end{array}$} & \multirow{2}{*}{$\frac{\text { D }}{14}$} & \multirow{2}{*}{$\begin{array}{c}\mathbf{N} \\
78\end{array}$} & \multirow{2}{*}{$\frac{\text { A }}{109}$} & \multirow{2}{*}{$\begin{array}{l}\text { SA } \\
99\end{array}$} & & \\
\hline Annual leadership evaluation of HODs should be undertaken & Count & & & & & & \multirow{2}{*}{3.86} & \multirow{2}{*}{1.038} \\
\hline by the respective staff & $\%$ & 3.8 & 4.5 & 25.0 & 34.9 & 31.7 & & \\
\hline \multirow{2}{*}{ My HOD is concerned about staff well-being } & Count & 62 & 85 & 84 & 57 & 24 & \multirow{2}{*}{2.67} & \multirow{2}{*}{1.205} \\
\hline & $\%$ & 19.9 & 27.2 & 26.9 & 18.3 & 7.7 & & \\
\hline \multirow{2}{*}{$\begin{array}{l}\text { I am able to discuss personal staff matters or report a problem } \\
\text { to my HOD }\end{array}$} & Count & 73 & 77 & 74 & 63 & 25 & \multirow{2}{*}{2.65} & \multirow{2}{*}{1.259} \\
\hline & $\%$ & 23.4 & 24.7 & 23.7 & 20.2 & 8.0 & & \\
\hline \multirow{2}{*}{ My HOD is my confidant and genuinely cares for me } & Count & 84 & 83 & 82 & 47 & 16 & \multirow{2}{*}{2.45} & \multirow{2}{*}{1.183} \\
\hline & $\%$ & 26.9 & 26.6 & 26.3 & 15.1 & 5.1 & & \\
\hline \multirow{2}{*}{$\begin{array}{l}\text { Staff are comfortable to raise the issues and ask the questions } \\
\text { to the HOD }\end{array}$} & Count & 76 & 82 & 57 & 71 & 25 & \multirow{2}{*}{2.64} & \multirow{2}{*}{1.290} \\
\hline & $\%$ & 24.4 & 26.4 & 18.3 & 22.8 & 8.0 & & \\
\hline \multirow{2}{*}{ I am involved in final decision-making } & Count & 89 & 95 & 77 & 38 & 13 & \multirow{2}{*}{2.33} & \multirow{2}{*}{1.136} \\
\hline & $\%$ & 28.5 & 30.4 & 24.7 & 12.2 & 4.2 & & \\
\hline \multirow{2}{*}{ I have a good working relationship with my HOD } & Count & 55 & 73 & 78 & 74 & 32 & \multirow{2}{*}{2.86} & 1.253 \\
\hline & $\%$ & 17.6 & 23.4 & 25.0 & 23.7 & 10.3 & & 1.253 \\
\hline & Count & 48 & 73 & 97 & 63 & 31 & & \\
\hline Thy HOU supports my career development & $\%$ & 15.4 & 23.4 & 31.1 & 20.2 & 9.9 & 2.86 & .197 \\
\hline Duties are allocated equitably to all staff & Count & 69 & 67 & 96 & 55 & 25 & 268 & 1224 \\
\hline Eutles are allocateu equilably to all stall & $\%$ & 22.1 & 21.5 & 30.8 & 17.6 & 8.0 & 2.08 & $.2 \angle 4$ \\
\hline & Count & 48 & 74 & 84 & 67 & 39 & & \\
\hline My HOD encourages teamwork & $\%$ & 15.4 & 23.7 & 26.9 & 21.5 & 12.5 & 2.92 & 1.251 \\
\hline & Count & 88 & 72 & 83 & 47 & 22 & & \\
\hline Thave the adequate resources to do my job well & $\%$ & 28.2 & 23.1 & 26.6 & 15.1 & 7.1 & 2.50 & 12 \\
\hline I am willing to go the extra mile to heln staff in my denartment & Count & 68 & 66 & 33 & 80 & 65 & 303 & 1476 \\
\hline I am willing to go the extra mile to neip stain in my aepartment & $\%$ & 21.8 & 21.2 & 10.6 & 25.6 & 20.8 & 3.03 & $.4 / 6$ \\
\hline feel part of a family & Count & 89 & 77 & 59 & 56 & 31 & 56 & 1333 \\
\hline I am nappy and teel part of a family to work & $\%$ & 28.5 & 24.7 & 18.9 & 17.9 & 9.9 & 2.56 & 1.333 \\
\hline & Count & 86 & 79 & 66 & 55 & 26 & & 1.288 \\
\hline My HOD inspires and encourages me to perform bett & $\%$ & 27.6 & 25.3 & 21.2 & 17.6 & 8.3 & 2.54 & 1.288 \\
\hline I switch a iob should a better iob offer ar & Count & 63 & 61 & 50 & 49 & 89 & & 1.514 \\
\hline I Will switch a job should a better job otter arise & $\%$ & 20.2 & 19.6 & 16.0 & 15.7 & 28.5 & 3.13 & 1.514 \\
\hline Average mean & & & & & & & 2.87 & 0.115 \\
\hline
\end{tabular}

Table 3. Components of leadership dimension concepts

\begin{tabular}{|c|c|c|c|c|c|c|c|c|}
\hline \multirow{2}{*}{ Leadership dimension concepts } & & \multicolumn{5}{|c|}{ Likert scale } & \multirow{2}{*}{ Mean } & \multirow{2}{*}{ Std. dev } \\
\hline & & SD & D & $\mathbf{N}$ & A & SA & & \\
\hline \multirow{2}{*}{ Leader's style has an impact on staff well-being } & Count & 9 & 7 & 34 & 113 & 149 & \multirow{2}{*}{4.24} & \multirow{2}{*}{0.939} \\
\hline & $\%$ & 2.9 & 2.2 & 10.9 & 36.2 & 47.8 & & \\
\hline \multirow{2}{*}{$\begin{array}{l}\text { An ethical leadership style can have a positive impact on the } \\
\text { employees }\end{array}$} & Count & 2 & 4 & 23 & 112 & 171 & \multirow{2}{*}{4.43} & \multirow{2}{*}{0.740} \\
\hline & $\%$ & 0.6 & 1.3 & 7.4 & 35.9 & 54.8 & & \\
\hline \multirow{2}{*}{ I am loyal to my organization } & Count & 6 & 9 & 44 & 105 & 148 & \multirow{2}{*}{4.22} & \multirow{2}{*}{0.927} \\
\hline & $\%$ & 1.9 & 2.9 & 14.1 & 33.7 & 47.4 & & \\
\hline \multicolumn{7}{|l|}{ Average mean } & 4.27 & 0.093 \\
\hline
\end{tabular}

\subsection{Inferential statistics}

\section{One-sample T-test}

In light of the preceding statistics, one sample $T$-test was performed, which uses mean score, standard deviation, and number of samples to calculate the test statistic. The hypotheses posited were as follows:
Does ethical leadership style significantly influence the employee engagement?

H1: Line management leadership has no significant influence on the EE.

H1: Line management leadership has significant influence on the EE. 
The results showed negative higher dimension of $t$-value for the majority of the statements. The outcome of the statistical results from the $p$-value revealed that there was a significant disagreement for overall employee engagement construct, as reported below:

- My HOD is concerned about staff well-being $(\mathrm{M}=2.67, \mathrm{SD}=1.205), \quad t(311)=-4.888$, $p=0.000$;

- I am able to discuss personal staff matters or report a problem to my HOD $(\mathrm{M}=2.65$, $\mathrm{SD}=1.259), t(311)=-4.945, p=0.000$;

- My HOD is my confidant and genuinely cares for me $(\mathrm{M}=2.45, \mathrm{SD}=1.183), t(311)=-8.232$, $p=0.000$;

- Staff are comfortable to raise issues and ask questions to the HOD $(\mathrm{M}=2.64, \mathrm{SD}=1.290)$, $t(310)=-4.967, p=0.000$;

- Iaminvolved in finaldecision-making $(\mathrm{M}=2.33$, $\mathrm{SD}=1.136), t(311)=-10.420, p=0.000$;

- I have a good working relationship with my HOD $(\mathrm{M}=2.86, \mathrm{SD}=1.253), t(311)=-2.033$, $p=0.043$;

- My HOD supports my career development $(\mathrm{M}=2.86, \mathrm{SD}=1.197), \quad t(311)=-2.081$, $p=0.038$;

- Duties are allocated equitably to all staff $(\mathrm{M}=2.68, \quad \mathrm{SD}=1.224), \quad t(311)=-4.625$, $p=0.000$;

- My HOD encourages teamwork $(\mathrm{M}=2.92$, $\mathrm{SD}=1.251), t(311)=-1.131, p=0.259$;

- I have the adequate resources to do my job well $(\mathrm{M}=2.50, \mathrm{SD}=1.242), t(311)=-7.155, p=0.000 ;$

- I am willing to go the extra mile to help staff in my department $(\mathrm{M}=3.03, \mathrm{SD}=1.476)$, $t(311)=0.307, p=0.759$;

- I am happy and feel part of a family to work in my department $(\mathrm{M}=2.56, \mathrm{SD}=1.333)$, $t(311)=-5.817, p=0.000$;
- MyHOD inspires and encourages me to perform better $(\mathrm{M}=2.54, \mathrm{SD}=1.288), t(311)=-6.332$, $p=0.000$; and

- I will switch a job should a better job offer arise $(\mathrm{M}=3.13, \mathrm{SD}=1.514), t(311)=1.496, p=0.136$.

Understandably, one of the aforesaid statements was integrated into significant agreement below, despite the results showing a $p$-value greater than 0.05 . One statement may possibly fall under the category of being similar to reverse score items which is comparable to Ilhan and Guler (2017, p. 322, cited in Bergstrom \& Luriz, 1998) that found direct and reverse scored items measured the same structure, and applying both of these items together was unobjectionable. The one statement showed a positive $t$-value dimension and revealed a statistical significant agreement whereby the annual leadership evaluation of HODs should be undertaken by the respective staff $(M=3.86$, $\mathrm{SD}=1.038), t(311)=14.672, p=0.000$.

\section{KEY RESULTS}

The analysis indicated that there was currently a lack of the EE occurring at the institution (Table 2). It further revealed a strong agreement of $66.6 \%$ by most respondents for annual leadership evaluation of HODs by the respective staff. Thus, the results have implied that more than half of these respondents believe that LML needs to be evaluated continuously. The one sample $t$-test indicated that a statistical significant disagreement existed for mean value of the EE variable for majority (14 out of 15) of the variables related to LML. It therefore shows a statistical significant disagreement for the overall EE construct. In addition, respondents believed that ethical leadership can have a positive impact on the employees, as shown in Table 3. Hence, $H 1_{0}$ is rejected. Therefore, $H 1_{1}$ (alternative hypothesis) is partially accepted.

\section{DISCUSSION}

Relating to the results found, the rationale behind leadership evaluation would be to facilitate better work relationships between LML and employees. In addition, it would examine any underlying 
issues between both these parties that may impact the teamwork, achievement of departmental goals and objectives. This is further affirmed by Brown and Treviño's (2006, p. 610) assertion that employees' evaluation of managers will offer the best assessment of ethical leadership, since employees work closely and have insight into the leader's behavior and performance. Drawing from the descriptive statistics, management styles influence both the output and the well-being of employees (Van Niekerk et al., 2017, p. 221, cited in Friedman, Tidd, Currall, \& Tsai, 2000; Wright, 2011). In addition, leadership styles can influence an employee to be motivated or disruptive based on leadership style. Leadership style in an institution plays an important role in improving or impeding the interest and commitment of the people (Obiwuru, Andy, Akpa, \& Nwankwere, 2011, p. 100). It was important for leadership to be role models and to lead by example. Ethical leaders are termed as individuals with right principles and strong character that serve as role models for others and resist temptations (Bello, 2012, p. 230). Activities such as teambuilding can motivate the employees by making them feel valued and promote team spirit. Council of Higher Education (2016, cited in Gourley, 2016, p. 58) claimed that a lot has been researched on management literature about the importance of teams and the team-building, as a leader cannot attend to all the responsibilities that require attention. Leadership should also be cognisant of employee job progress and promotion in order to motivate the employees. Leader has the ability and authority to provide the things that employees desires for acceptable behavior, e.g., salary increases, promotions and other forms of acknowledgement (Van Zyl et al., 2016, pp. 272-274, cited in Pietersen, 2016).
Leaders did acknowledge that employees should be kept happy and viewed well-being, drive and commitment as important in their departments. Ethical leadership is firmly connected to well-being (Kalshoven \& Boon, 2012, p. 60), thus, could enhance the productivity, as engagement had a positive effect on work and productivity. It is vital from a management viewpoint to note that the intellectual capital of employees itself is the principal asset of the organization (Denton \& Vloeberghs, 2003, p. 88, cited in Handy, 1997). However, it was evident that the processes to support employee well-being, drive, and commitment were limited. The study findings have shown that a lack of ethical leadership style had an adverse effect on the EE. This shows the relationship between ethical leadership style and the EE, which can be concurred by Men's (2014) assertion that ethical leadership communication inspires the EE. Moreover, the main features of ethical leadership style are to be moral, transparent, and have integrity regardless of institutional constraints or challenges. When employees view leadership as ethical, they will follow the leader and be inspired to become better employees or better future leaders. Evidently, most of the findings have revealed that these managers have not conformed to or exhibit the ethical leadership style, which has resulted in the employee disengagement. The findings have shown that ethical leadership can significantly influence the $\mathrm{EE}$ at the institution. However, these findings have also indicated a lack of the EE at the institution. Furthermore, the alternative hypothesis testing was accepted for leadership having a significant influence on the EE.

\section{CONCLUSION}

The study concludes that there is a current lack of the EE occurring between the respective leaders and their employees at the institution. The alternative hypothesis testing was accepted for leadership has a significant influence on the EE. More importantly, ethical leadership style can impact positively on the EE whereby the respondents believed that ethical leadership can influence the employee behavior and mindset while also contributing to motivation, drive, commitment, and feeling valued. This can have a positive effect on work and productivity. Lastly, it was also important for the leaders to be role models and to lead by example, despite the university constraints and process limitations. 


\section{REFERENCES}

1. Barkhuizen, N., \& Rothmann, S. (2008). Occupational Stress of Academic Staff in South African Higher Education Institutions. South African Journal of Psychology, 38(2), 321336. https://doi.org/10.1177\% 2F008124630803800205

2. Bello, S. M. (2012). Impact of ethical leadership on employee job performance. International Journal of Business and Social Science, 3(11), 228-234. Retrieved from https://www.researchgate. net/publication/296696360_The_ impact_of_ethical_leadership_on_ employee_job_performance

3. Bezuidenhout, A., \& Cilliers, F. V. (2010). Burnout, work engagement and sense of coherence in female academics in higher-education institutions in South Africa. SA Journal of Industrial Psychology, 36(1), 1-10. Retrieved from https://sajip. co.za/index.php/sajip/article/ view/872/956

4. Breevaart, K., Bakker, A., Hetland, J., Demerouti, E., Olsen, O. K., \& Espevik, R. (2014). Daily transactional and transformational leadership and daily employee engagement. Journal of Occupational and Organizational Psychology, 87(1), 138-157. https://doi.org/10.1111/ joop. 12041

5. Brown, M. E. (2007). Misconceptions of Ethical Leadership: How to Avod Potential Pitfalls. Organizational Dynamics, 36(2), 140-155. https://doi.org/10.1016/j.orgdyn.2007.03.003

6. Brown, M. E., \& Treviño, L. K. (2006). Ethical Leadership: a review and future directions. The Leadership Quaerterly, 17(6), 595616.

7. Brown, M. E., Treviño, L. K., \& Harrison, D. A. (2005). Ethical leadership: A social learning perspective for construct development and testing. Organizational Behavior and Human Decision Processes, 97(2), 117-134. https://doi.org/10.1016/j. obhdp.2005.03.002
8. Butcher, W. (1997). The need for ethical leadership. Executive Speeches, 11(5), 83-86. Retrieved from https://www.questia.com/ magazine/1G1-132417706/theneed-for-ethical-leadership

9. Carson, C. M., \& King, J. E. Jr. (2005). Leaving leadership: Solving leadership problems through empowerment. Management Decision, 43(7/8), 1049-1053. https://doi. org/10.1108/00251740510610044

10. Cawe, M. (2006). Factors contributing to employee engagement in South Africa (Faculty of Commerce, Law and Management. Johannesburg, University of the Witwatersrand, Johannesburg. Masters degree, 92). Retrieved from http://hdl.handle. net/10539/2031

11. Chen, J.-C., \& Silverthorne, C. (2005). Leadership effectiveness, leadership style and employee readiness. Leadership \& Organization Development Journal, 26(4), 280-288. https://doi. org/10.1108/01437730510600652

12. Cook, S. (2008). What is employee engagement? London, GBR, Kogan Page Publishers.

13. Council of Higher Education (2016). Reflections of South African university leaders 1981 to 2014. Retrieved from https://www. amazon.co.uk/Reflections-SouthAfrican-University-Leaders/ dp/1928331092

14. Cropanzano, R., \& Wright, T. A. (2001). When a "happy" worker is really a "productive" worker: A review and further refinement of the happy-productive worker thesis. Consulting Psychology Journal: Practice and Research, 53(3), 182-199. Retrieved from https://www.researchgate.net/ publication/232457601_When_a_ Happy_Worker_Is_Really_a_Productive_Worker_A_Review_and_ Further_Refinement_of_the_Happy-Productive_Worker_Thesis

15. De Hoogh, A. H., \& Den Hartog, D. N. (2008). Ethical and despotic leadership, relationships with leader's social responsibility, top management team effectiveness and subordinates' optimism:

A multi-method study. The Leadership Quarterly, 19(3), 297311. https://doi.org/10.1016/j. leaqua.2008.03.002

16. Deligero, J. C. L., \& Laguador, J. M. (2014). Work engagement among employees and its relationship with work units' performance of a higher education institution. International Journal of Management Sciences, 3(12), 909917. Retrieved from https://ideas. repec.org/a/rss/jnljms/v3i12p5. html

17. Denton, M., \& Vloeberghs, D. (2003). Leadership challenges for organisations in the new South Africa. Leadership \& Organization Development Journal, 24(2), 84-95. https://doi. org/10.1108/01437730310463279

18. Detert, J. R., Treviño, L. K., \& Sweitzer, V. L. (2008). Moral disengagement in ethical decision making: a study of antecedents and outcomes. The Journal of applied psychology, 93(2), 374-391. Retrieved from https://www.ncbi. nlm.nih.gov/pubmed/18361639

19. Devi, V. R. (2009). Employee engagement is a two-way street. Human Resource Management International Digest, 17(2), 3-4. https://doi. org/10.1108/09670730910940186

20. Dromey, J. (2014). Macleod and Clarke's concept of employee engagement: an analysis based on the Workplace Employment Relations Study.

21. Eisenbeiss, S. A., \& Brodbeck, F. (2014). Ethical and unethical leadership: A cross-cultural and cross-sectoral analysis. Journal of Business Ethics, 122(2), 343359. Retrieved from https://link. springer.com/article/10.1007/ s10551-013-1740-0

22. Engelbrecht, A. S., Heine, G., \& Mahembe, B. (2014). The influence of ethical leadership on trust and work engagement: An exploratory study. SA Journal of Industrial Psychology, 40(1). https://doi.org/10.4102/sajip. v40i1.1210 
23. Field, L. K., \& Buitendach, J. H. (2011). Happiness, work engagement and organisational commitment of support staff at a tertiary education institution in South Africa. SA Journal of Industrial Psychology, 37(1), 1-10. Retrieved from https://sajip. co.za/index.php/sajip/article/ view/946/1073

24. Gallup (2016). The Engaged University. Higher Education Employee Engagement. Retrieved from https://www.gallup.com/education/194321/higher-educationemployee-engagement.aspx

25. Greco, P., Laschinger, H., \& Wong, C. A. (2006). Leader empowering behaviours, staff nurse empowerment and work engagement/burnout. Nursing Leadership, 19(4), 41-56. https:// doi.org/10.12927/cjnl.2006.18599

26. Gumede, D. C. (2014). The challenges of working and studying at a satellite campus: a case study of the Riverside Campus of the Durban University of Technology (304 p.) (Doctor of technology in business administration). Durban, Kwa-Zulu Natal, DUT.

27. Halbesleben, J. R., \& Wheeler, A. R. (2008). The relative roles of engagement and embeddedness in predicting job performance and intention to leave. Work \& Stress, 22(3), 242-256. Retrieved from https://psycnet.apa.org/record/2008-14200-005

28. Hanson, K., \& Léautier, F. (2011). Enhancing institutional leadership in African universities: Lessons from ACBS's interventions. World Journal of Entrepreneurship, Management and Sustainable Development, 7(2/3/4), 385-417.

29. Herbst, T. H., \& Conradie, P. D. (2011). Leadership effectiveness in Higher Education: Managerial self-perceptions versus perceptions of others. SA Journal of Industrial Psychology, 37(1), 1-14. Retrieved from https://sajip. co.za/index.php/sajip/article/ view/867/1000

30. Heres, L., \& Lasthuizen, K. (2013). From ethical competence to ethical leadership. Achieving Ethical Competence for Public
Service Leadership, 51. Retrieved from https://www.researchgate. net/publication/264421267_From_ ethical_competence_to_ethical_leadership

31. Hirtle, C. (2016). Employee engagement for Workplace success. Message from the president, 2016. Retrieved from www.csmls.org

32. İlhan, M., \& Güler, N. (2017). The Number of Response Categories and the Reverse Directional Item Problem in Likert-Type Scales: A Study with the Rasch Model. Eğitimde ve Psikolojide Ölçme ve Değerlendirme Dergisi, 8(3), 321-343. Retrieved from https:// www.researchgate.net/publication/320132236_The_Number_of_ Response_Categories_and the Reverse_Scored_Item_Problem_ in_Likert-Type_Scales_A_Study_ with_the_Rasch_Mode

33. Institute of Directors South Africa report (IODSA) (2016). King IV report on corporate governance for South Africa 2016. South Africa. Retrieved from https:// home.kpmg/za/en/home/insights/2016/10/king-iv-report-oncorporate-governance-for-southafrica-2016.html

34. Jackson, L. T., Rothmann, S., \& Vijver, F. J. R. (2006). A model of work-related well-being for educators in South Africa. Stress and Health: Journal of the International Society for the Investigation of Stress, 22(4), 263-274. https://doi.org/10.1002/ smi.1098

35. Jackson, L., \& Rothmann, S. (2005). Work-related well-being of educators in a district of the North-West Province: research article: general. Perspectives in Education, 23(1), 107-122. Retrieved from https://journals. co.za/content/persed/23/1/ EJC87328

36. Kalshoven, K., \& Boon, C. T. (2012). Ethical Leadership, Employee Well-Being, and Helping. Journal of Personnel Psychology, 11(1), 60-68. https:// doi.org/10.1027/1866-5888/ a000056

37. Kalshoven, K., \& Den Hartog, D. N. (2009). Ethical leader behavior and leader effectiveness: The role of prototypicality and trust. International Journal of Leadership Studies, 5(2), 102-120. Retrieved from https://dare.uva.nl/ search?identifier $=421 \mathrm{~b} 1569-98 \mathrm{da}-$ 49d4-adff-3f04d1427822

38. Kompaso, S. M., \& Sridevi, M. S. (2010). Employee Engagement: The key to Improving Performance. International Journal Of Business And Management, 5(12), 89. https://doi.org/10.5539/ ijbm.v5n12p89

39. Konrad, A. M. (2006). Engaging employees through highinvolvement work practices. Ivey Business Journal, 70(4), 1-6.

40. Lewis, A., Brychan, T., \& Owen, B. (2012). Employee socialisation: A platform for employee engagement? International Journal of Employment Studies, 20(1), 25. Retrieved from https://search. informit.com.au/documentSum mary;dn=891614549415477;res= IELBUS

41. Masemola, S. E. (2011). Employee turnover intentions, organisational commitment and job satisfaction in a post-merger tertiary institution: the case of the University of Limpopo (129 p.) (Master of Business Administration). Human Resource Management. South Africa, University of Limpopo. Retrieved from http://ulspace. ul.ac.za/handle/10386/484

42. Mayer, D. M., Kuenzi, M., Greenbaum, R., Bardes, M., \& Salvador, R. (2009). How low does ethical leadership flow? Test of a trickle-down model. Organizational Behavior and Human Decision Processes, 108(1), 1-13. https://doi.org/10.1016/j. obhdp.2008.04.002

43. Men, L. R. (2014). Does ethical leadership communication engage employees? Retrieved from https:// instituteforpr.org/ethical-leadership-communication-engage-employees/ (accessed on November 21, 2015

44. Mitchell, T. R., Holton, B. C., Lee, T. W., \& Graske, T. (2001). How to keep your best employees: Developing an effective retention policy. Academy of Management Perspectives, 15(4), 96-109. 
Retrieved from https://www.jstor. org/stable/4165789? seq =1

45. Oates, V. (2013). Instilling Ethical Leadership in Business. Retrieved from http://www.gaaaccounting. com/instilling-ethical-leadershipin-business/ (accessed on June 27, 2013).

46. Obiwuru, T. C., Andy, T., Akpa, V., \& Nwankwere, I. (2011). Effects of leadership style on organizational performance: A survey of selected small scale enterprises in Ikosi-Ketu council development area of Lagos State, Nigeria. Australian Journal of Business and Management Research, 1(7), 100. Retrieved from http:// citeseerx.ist.psu.edu/viewdoc/ summary? doi=10.1.1.463.7171

47. Quintal, G. (2012). Public protector: What we need are ethical leaders (News). Retrieved from https://mg.co.za/article/201203-13-what-we-need-are-ethicalleaders-public-protector

48. Rothmann, S., \& Jordaan, G. (2006). Job demands, job resources and work engagement of academic staff in South African higher education institutions. $S A$ Journal of Industrial Psychology, 32(4), 87-96. Retrieved from https://sajip.co.za/index.php/sajip/ article/view/247

49. South African Institute of Professional Accountants (SAIPA) (2017). Ethics and Integrity of a professiona accountant. Journal of the South African Institute of Professional Accountants, 10-11.

50. Schaufeli, W. B., Salanova, M., Gonzalez-romá, V., \& Bakker, A. (2002). The Measurement of Engagement and Burnout: A Two Sample Confirmatory Factor Analytic Approach. Journal of Happiness Studies, 3(1), 71-92. Retrieved from https://link.springer.com/ article/10.1023/A:1015630930326

51. Schaufeli, W., \& Bakker, A. (2001). Work and well-being: towards a positive approach in occupational health psychology. Gedrag \& Organisatie, 14, 229253. Retrieved from https:// www.researchgate.net/publication/287890847_Work_and_well-
being_Towards_a_positive_occupational_health_psychology

52. Schulze, S. (2006). Factors influencing the job satisfaction of academics in higher education. South African Journal of Higher Education, 20(2), 318-335. Retrieved from https://www. researchgate.net/publication/228729942_Factors_influencing_the_job_satisfaction_of_academics_in_higher_education

53. Shaw, K., \& Bastock, A. (2005). Employee engagement: How to build a high-performance workforce. Chicago: Melcrum Publishing Limited.

54. Shuck, B., \& Wollard, K. (2010). Employee engagement and HRD: A seminal review of the foundations. Human Resource Development Review, 9(1), 89-110.

55. Sonnentag, S. (2003). Recovery, work engagement, and proactive behavior: a new look at the interface between nonwork and work. The Journal of Applied Psychology, 88(3), 518-528. Retrieved from https://psycnet. apa.org/record/2003-00755-014

56. Sullivan, B., Bartlett, K. R., \& Rana, S. (2015). The Role of Strategic $H R D$ in Establishing Employee Engagement Initiatives: A Case Study from Higher Education (16th International HRD Conference Cork). Ireland.

57. Swarnalatha, C., \& Prasanna, T. (2013). Employee engagement: The concept. International Journal of Management Research and Reviews, 3(12), 3872.

58. Takawira, N., Coetzee, M., \& Schreuder, D. (2014). Job embeddedness, work engagement and turnover intention of staff in a higher education institution: an exploratory study: original research. SA Journal of Human Resource Management, 12(1), 1-10. https://doi.org/10.4102/sajhrm. v12i1.524

59. Treviño, L. K., Brown, M., \& Hartman, L. P. (2003). A Qualitative Investigation of Perceived Executive Ethical Leadership: Perceptions from Inside and Outside the Executive
Suite. Human Relations, 56(1), 5-37. https://doi.org/10.1177\% 2F0018726703056001448

60. Treviño, L. K., Hartman, L. P., \& Brown, M. (2000). Moral Person and Moral Manager: How Executives Develop a Reputation for Ethical Leadership. California Management Review, 42(4), 128142. Retrieved from https://store. hbr.org/product/moral-personand-moral-manager-how-executives-develop-a-reputation-forethical-leadership/CMR183

61. Van Niekerk, W. M., De Klerk, M., \& Pires-Putter, J. K. (2017). Conflict management styles and work-related well-being among higher education employees. Journal of Psychology in Africa, 27(3), 221-226. https://doi.org/10. 1080/14330237.2017.1321841

62. Van Zyl, E., Dalgish,C., du Plessis, M., Lues, L., Pietersen, E., Ngunjiri, F., \& Kablan, P. (2016). Leadership in the African Context. Cape Town, Juta and Co (Pty) Ltd. 